\title{
Chiral thiazolidine based organocatalysts: synthesis and application in asymmetric aldol reactions
}

\author{
Ana Rita G. Félix, Pedro R. D. Simões, Francisco J. P. M. Sousa, M. Elisa Silva Serra, Dina Murtinho* \\ CQC, Department of Chemistry, University of Coimbra
}

\begin{tabular}{l}
\hline A R T I C L E H I S T O R Y \\
\hline Received: \\
Revised: \\
Accepted: \\
DOI:
\end{tabular}

\begin{abstract}
Several novel chiral organocatalysts derived from thiazolidines containing amide and thioureia functionalities were synthesized in good yields. These organocatalysts were tested in the asymmetric aldol reaction of acetone with $p$-nitrobenzaldehyde. Reaction parameters such as reaction time, catalyst loading and solvent were optimized. Products with enantiomeric ratios $(e r)$ up to 84.5:15.5 $(R: S)$ were obtained. The effect of several chiral and non-chiral additives on the reactivity and selectivity of the reaction was also evaluated. With our best organocatalyst the reaction was extended to other aromatic aldehydes and when p-bromobenzaldehyde was used an $e r$ of 94.5:5.5 $(R: S)$ was obtained.
\end{abstract}

Keywords: Thiazolidines, organocatalyst, aldol reaction, enantioselective, asymmetric synthesis, additives.

\section{INTRODUCTION}

The research on catalytic methods using chiral organocatalysts has considerably increased in recent years since these catalysts proved to be very efficient in several asymmetric reactions.[1-4] Organocatalysts present several advantages over organometallic compounds or enzymes, namely, the absence of metals, which are difficult to remove and environmentally polluting, the fact that anhydrous and inert conditions are not usually necessary and milder reaction conditions can usually be used.[5]

Although the use of chiral organic compounds to catalyze asymmetric reactions was already known at the beginning of the last century, it was not until the 1970s, when Hajos and Parrish published the first proline-catalyzed aldol reaction with high enantioselectivity,[6] that this area attracted the attention of the scientific community. However, most of the work published during the end of the $20^{\text {th }}$ century was limited to the use of proline and cinchona-derived alkaloids as chiral organocatalysts. It was only in the beginning of this century that this area experienced a great expansion, especially when the mechanisms of action of these catalysts were established.[3] Currently, there are numerous examples in the literature of the use of organocatalysts, with diverse structures and functionalities, such as amines, acids, ureas, thioureas, alcohols, guanidines, etc.

The organocatalyzed asymmetric aldol reaction is a C-C bond forming reaction, whose products, $\beta$-hydroxycarbonyl

*Department of Chemistry, Rua Larga, University of Coimbra, 3004-535 Coimbra, Portugal, Phone: +351 239 854478, e-mail: dmurtinho@ci.uc.pt compounds can be found in various natural products. This reaction has been widely explored and there are many examples in the literature of catalysts developed for this transformation, which originate high selectivity.[7-11]

The publication by List et al., in 2000, [12] describing the asymmetric aldol reaction between acetone and a variety of aldehydes, using proline as organocatalyst, originated the development of many proline-derived organocatalysts that resulted in excellent asymmetric reactions.[13] Thiazolidines have some structural similarities to proline, namely, a 5membered ring containing a nitrogen atom. Chiral thiazolidines can be readily synthesized by reaction of Lcysteine with aldehydes. Unlike proline, organocatalysts derived from thiazolidines are less exploited. However, there are several references in the literature to the use of some thiazolidines in asymmetric reactions. For example, Barbas III et al. refer the use of thiazolidines derived from Lcysteine and D-penicillamine in aldol reactions, with very promising results.[14] More recently, Schneider et al. developed several chiral thiazolidine-derived organocatalysts that were used in aldol reactions.[15,16] In this context, and in the continuation of our studies on the use of thiazolidines for asymmetric catalysis,[17] a series of new thiazolidine organocatalysts were synthesized and tested in asymmetric aldolic reactions. The results of these studies are described in this paper.

\section{RESULTS AND DISCUSSION}

\subsection{Organocatalyst synthesis}

Thiazolidine 1 was synthesized, in 93\% yield, from the condensation of L-cysteine with formaldehyde according to a previously described procedure. Compound $\mathbf{1}$ was then 
treated with di-tert-butyl dicarbonate, in the presence of sodium carbonate at room temperature, to give product $\mathbf{2}$ in $85 \%$ yield. Reaction of 2 with ethyl chloroformate, in the presence of $\mathrm{NEt}_{3}$ at room temperature, followed by reaction with $o$-aminophenol, $o$-diaminobenzene or benzylamine gave $\mathbf{3 , 4}$ and 5, respectively, in moderate yields. Deprotection of the thiazolidine nitrogen, using neat formic acid, allowed the synthesis of organocatalysts $\mathbf{3 a}, \mathbf{4 a}$ and $\mathbf{5 a}$ in good yields (Scheme 1).

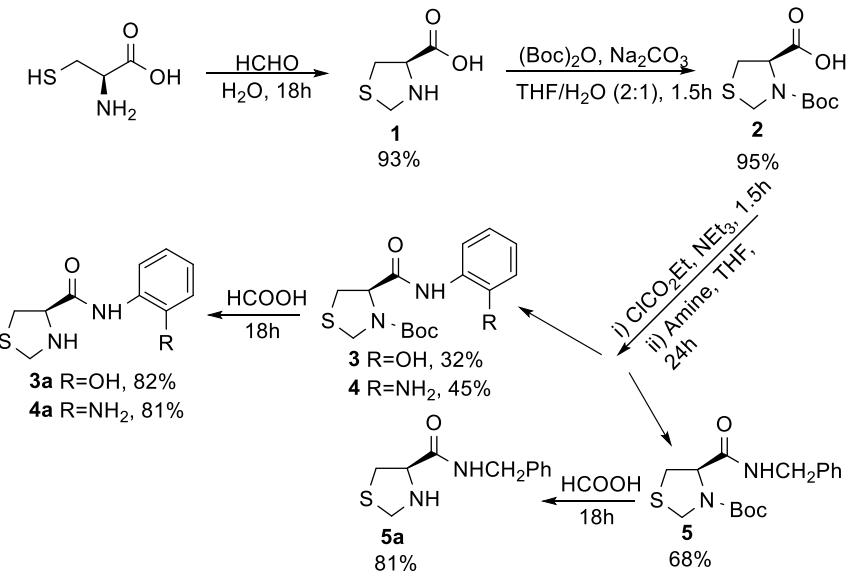

SCHEME 1 Synthesis of organocatalysts 3a-6a.

Thiourea derivatives constitute a privileged class of organocatalysts due to the possibility of establishing multiple hydrogen-bond interactions with substrates, when used in asymmetric catalysis[22,23]. Although several thioureas derived from proline have been synthesized and used as organocatalysts in various asymmetric reactions with high stereoselectivities,[24-30] thioureas derived from thiazolidines are scarce in the literature. Schneider and coworkers reported, in 2015, the synthesis of thioureas containing a thiazolidine moiety. However, they were not used as organocatalyst, but were tested for their antioxidant activity.[31] Therefore, we decided to synthetize new thioureas derived from thiazolidine $\mathbf{4}$ to test in asymmetric aldol reactions.

Reaction of 4 with phenyl isothiocyanate or 3,5bis(trifluoromethyl)phenyl isothiocyanate, in dichloromethane at room temperature, allowed the synthesis of compounds 6 and 7 in $85 \%$ and $99 \%$ yield, respectively. Thioureias $6 \mathbf{a}$ and $7 \mathbf{a}$ were obtained after the removal of the $N$-Boc protecting group with formic acid in $73 \%$ and $86 \%$ yield, respectively (Scheme 2).

In order to compare the effect of the presence of the thiourea with an amide moiety, organocatalyst 8a was also prepared. Compound $\mathbf{8}$ was obtained by reaction of $\mathbf{4}$ with benzoyl chloride, in the presence of $\mathrm{NEt}_{3}$ at room temperature, in $84 \%$ yield, followed by deprotection of the nitrogen to give $\mathbf{8 a}$ in $80 \%$ yield (Scheme 2).

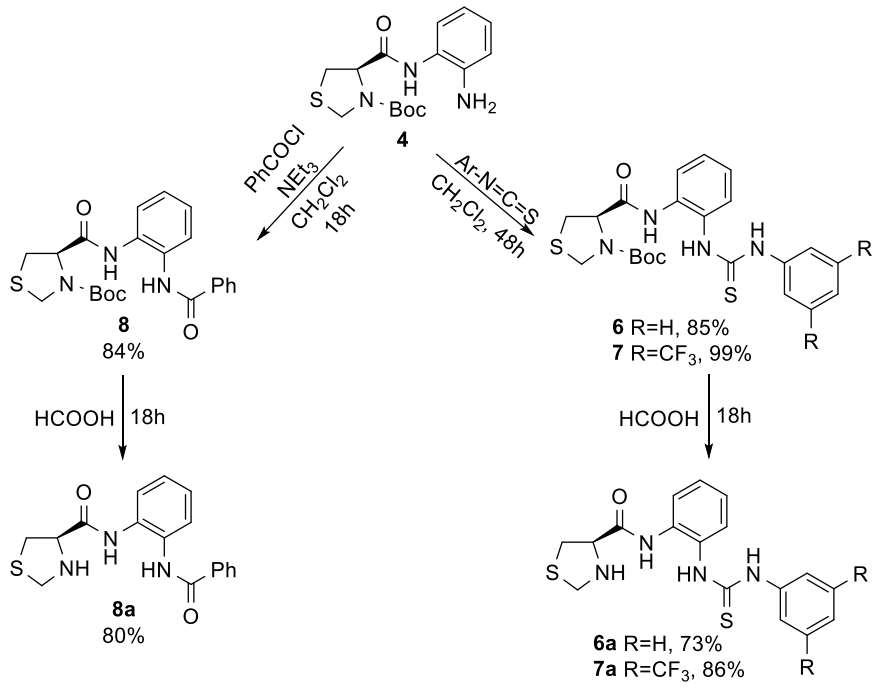

SCHEME 2 Synthesis of organocatalysts 6a-8a.

\subsection{Asymmetric aldol reactions}

Organocatalyst 3a was first tested in the asymmetric aldol reaction between $p$-nitrobenzaldehyde and acetone, at room temperature using acetone as solvent and reagent. Reaction conditions such as reaction time and catalyst loading were optimized, and best results were obtained using $20 \mathrm{~mol} \%$ of the organocatalyst after 5 days reaction time, $49 \%$ yield and er of 54:46 $(R: S)$. Using these conditions, organocatalysts 3a-8a were screened for their catalytic activity in the asymmetric aldol reaction (Scheme 3 and Table 1).

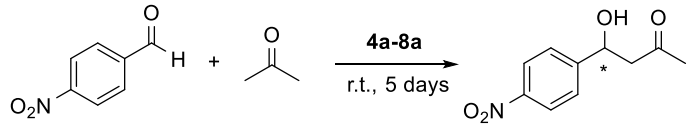

SCHEME 3 Aldol reaction.

Table 1. Aldol reaction between $p$-nitrobenzaldehyde and

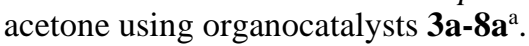

\begin{tabular}{|c|c|c|}
\hline Organocatalyst & Yield (\%) & er (\%) $(\boldsymbol{R}: S)$ \\
\hline 3a & 49 & $59: 41$ \\
\hline $\mathbf{4 a}$ & 12 & n.d. \\
\hline $\mathbf{5 a}$ & 32 & $50: 50$ \\
\hline $\mathbf{6 a}$ & 50 & $84.5: 15.5$ \\
\hline $\mathbf{7 a}$ & 84 & $70: 30$ \\
\hline $\mathbf{8 a}$ & 25 & $50: 50$ \\
\hline
\end{tabular}

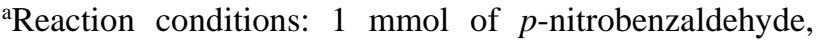
$2 \mathrm{~mL}$ of acetone, $20 \mathrm{~mol} \%$ of organocatalyst, 5 days, room temperature; n.d. (not determined).

The results presented in table 1 show that low yields and racemic products were obtained with organocatalysts $\mathbf{4 a}, \mathbf{5 a}$ and 8a. Compound 7a was the most active in promoting the aldol reaction ( $84 \%$ yield), although the obtained er was 
moderate, 70:30 (R:S). The best er was achieved with thiourea 6a, 84.5:15.5 (R:S).

Since thiourea $7 \mathbf{a}$ proved to be the most active organocatalyst, the aldol reaction was carried out at $0{ }^{\circ} \mathrm{C}$ in order to determine the effect of lowering the temperature on the $e r$. Although the $e r$ did increase to 85.5:14.5, the yield of the reaction decreased to $33 \%$, after a reaction time of 5 days. Thus, thiourea $\mathbf{6 a}$ was used to proceed the studies.

The solvent effect on the aldol reaction was evaluated using compound $\mathbf{6 a}$ and the obtained results are presented in Table 2.

Table 2. Solvent effect on the aldol reaction between $p$ nitrobenzaldehyde and acetone with $\mathbf{6} \mathbf{a}^{\mathrm{a}}$.

\begin{tabular}{|c|c|c|}
\hline Solvent & Yield (\%) & $\boldsymbol{e r}(\boldsymbol{\%})(\boldsymbol{R}: \mathbf{S})$ \\
\hline Acetone & 50 & $84.5: 15.5$ \\
\hline Acetone:brine $(4: 1)$ & 53 & $57: 43$ \\
\hline Acetone:water $(4: 1)$ & 55 & $62.5: 37.5$ \\
\hline Dichloromethane & 40 & $67.5: 32.5$ \\
\hline Acetonitrile & 13 & n.d. \\
\hline Dimethylsulfoxide & 15 & n.d. \\
\hline
\end{tabular}

${ }^{a}$ Reaction conditions: $1 \mathrm{mmol}$ of $p$-nitrobenzaldehyde, 4 mmol of acetone, $2 \mathrm{~mL}$ of solvent, $20 \mathrm{~mol} \%$ of organocatalyst 6a, 5 days, room temperature; n.d. (not determined).

Mixtures of acetone:brine and acetone:water were first tested as solvents, since they presented good results in aldol reactions catalyzed by thiazolidines, as described by Schneider and Rambo[15]. Using organocatalyst 6a, yields of $53 \%$ and $55 \%$ were obtained, which compare well with those obtained with acetone alone. However, poorer er were observed for the mixtures. The use of several other solvents in aldol reactions are reported in the literature, namely chorinated solvents and polar aprotic solvents such as $\mathrm{CH}_{3} \mathrm{CN}$ and DMSO.[32-34] A decrease in the reaction yields and $e r$ was observed when dichloromethane was used as solvent and with $\mathrm{CH}_{3} \mathrm{CN}$ and DMSO very low yields were obtained.

One of the strategies used to enhance reactivity and/or selectivity in catalytic reactions comprises the use of additives. These may have several functions, namely, activate of the substrate, contribute to the formation of a more stable and/or stereoselective transition state and prevent side reactions. In amine organocatalysed aldol reactions, whose mechanism involves the formation of iminium ions or enamines as intermediates, the use of acids as additives can accelarate their formation, activate the substrate or allow the realease of the product.[35] Accordingly, various organic and inorganic acids have been used as additives in aldol reactions, namely benzoic acid and derivatives, acetic acid, TFA, TsOH, chloroacetic acid, among others.[9,36-38] The use of chiral acids such as camphorsulfonic acid has also been described.[39-42] Besides acids, the use of alcohols, water and bases have also been referred.[30,32,36,43]
The effect of using acid addtives in the aldol reaction with organocatalyst $\mathbf{6 a}$ was evaluated and the results are presented in Table 3.

Table 3. Additive effect on the aldol reaction between $p$ nitrobenzaldehyde and acetone with $\mathbf{6} \mathbf{a}^{\mathrm{a}}$.

\begin{tabular}{|c|c|c|}
\hline Additive (pKa) & Yield (\%) & $\boldsymbol{e r}(\boldsymbol{\%})(\boldsymbol{R}: \boldsymbol{S})$ \\
\hline--- & 50 & $84.5: 15.5$ \\
\hline Benzoic acid & 66 & $62.5: 37.5$ \\
\hline$p$-Nitrobenzoic acid & 60 & $67: 33$ \\
\hline Acetic acid & 51 & $63: 37$ \\
\hline $\begin{array}{c}(1 R)-(-)-10-C a m p h o r- \\
\text { sulfonic acid }\end{array}$ & 25 & $50: 50$ \\
\hline $\begin{array}{c}(1 S)-(-)-10-C a m p h o r- \\
\text { sulfonic acid }\end{array}$ & 8 & n.d. \\
\hline$(S)-(+)-$ Mandelic acid & 69 & $71.5: 28.5$ \\
\hline
\end{tabular}

${ }^{a}$ Reaction conditions: $1 \mathrm{mmol}$ of $p$-nitrobenzaldehyde, $2 \mathrm{~mL}$ of acetone, $20 \mathrm{~mol} \%$ of organocatalyst $6 \mathbf{6}, 10 \mathrm{~mol} \%$ additive, 5 days, room temperature; n.d. (not determined).

Although the use of achiral acids such as benzoic and $p$ nitrobenzoic improved the yield of the reaction, the resulting er were lower than those obtained in the absence of the additives. The use of chiral acids was also evaluated and it was verified that both enantiomers of the bulky 10camphorsulfonic acid gave poor yields whereas $(S)-(+)-$ mandelic acid presented a better yield and a moderate $\mathrm{er}$.

Using organocatalysts 5a and 8a, that had given low yields and racemic products, we decided to determine whether in this case the presence of additives could improve the outcome of the reaction. The results are summarized in Table 4.

Table 4. Additive effect on aldol reaction between $p$ nitrobenzaldehyde and acetone with $\mathbf{5 a}$ and $\mathbf{8} \mathbf{a}^{\mathbf{a}}$.

\begin{tabular}{|c|c|c|c|}
\hline Additive & Organocatalyst & Yield (\%) & er (\%) $(\boldsymbol{R}: \boldsymbol{S})$ \\
\hline--- & $\mathbf{5 a}$ & 32 & $50: 50$ \\
& $\mathbf{8 a}$ & 25 & $50: 50$ \\
\hline Benzoic acid & $\mathbf{5 a}$ & $>99$ & $62: 38$ \\
& $\mathbf{8 a}$ & 93 & $71: 29$ \\
\hline Acetic acid & $\mathbf{5 a}$ & 55 & $50: 50$ \\
& $\mathbf{8 a}$ & 98 & $70.5: 29.5$ \\
\hline (R)-(-)- & $\mathbf{5 a}$ & 80 & $62.5: 37.5$ \\
Mandelic acid & $\mathbf{8 a}$ & 85 & $76: 24$ \\
\hline (S)-(+)- & $\mathbf{5 a}$ & 76 & $61.5: 38.5$ \\
Mandelic acid & $\mathbf{8 a}$ & 87 & $74: 26$ \\
\hline 4- $t$ - & $\mathbf{5 a}$ & 15 & n.d. \\
Butylphenol & & & \\
\hline
\end{tabular}

${ }^{\mathrm{a}}$ Reaction conditions: $1 \mathrm{mmol}$ of $p$-nitrobenzaldehyde, $2 \mathrm{~mL}$ of acetone, $20 \mathrm{~mol} \%$ of organocatalyst, $10 \mathrm{~mol} \%$ additive, 5 days, room temperature; n.d. (not determined). 
With the exception of 4-t-butylphenol, all the additives used resulted in an increase in the yield of the reaction. With organocatalysts 5a, best yields were obtained with benzoic acid as additive, conversions $>99 \%$. With $8 \mathbf{a}$ best yields resulted when benzoic and acetic acids were used, 93\% and 98\% conversions, respectively. The use of additives also improved the enantiomeric ratio for both catalysts, mainly with 8a. It should be noted that the use of $(R)$ - and $(S)$ Mandelic acid, chiral additives with opposite configurations, gave aldol products with $R$ configuration and similar $e r$. This result suggests that no match/mismatch effect is observed in this case. The best result was obtained with organocatalyst 8a and $(R)-(-)$-mandelic acid as additive, an er of 76:24 $(R: S)$, being observed for the product.

Gryko et al.[44] synthesized a thioamide 9 derived from proline, which was tested in aldol reactions in the presence of various acid additives. These authors observed that in acidic medium the protonated organocatalyst $\mathbf{9}$ could react with acetone to form imidazolidimethione 10, which lacks the ability to continue the catalytic cycle, or the iminium salt 11, which reacts with the aldehyde and continues the catalytic cycle. Using acids as additives, these authors verified that there is a correlation between the percentages of $\mathbf{9 , 1 0}$ and $\mathbf{1 1}$ in the reaction medium and the pKa of the acid additive (Scheme 4). Formation of $\mathbf{1 1}$ in greater quantity leads to a better efficiency of the organocatalyst, especially at the conversion level.

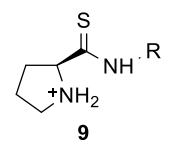

9
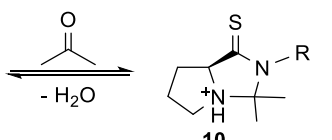

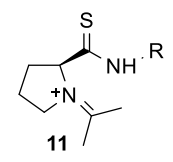

SCHEME 4 Equilibrium species from reaction of thioamide 9 with acetone.

Our study shows that it is possible to improve the yield and the er using acid additives in the asymmetric aldol reaction catalyzed by thiazolidine based organocatalysts. However, of all organocatalysts tested under the different reaction conditions, it was in the presence of $\mathbf{6 a}$, without any additive, that the product with highest er was formed, 84.5:15.5 (R:S). Therefore, using this organocatalysts without any additive, the reaction was extended to other aromatic aldehydes. The results of this study are summarized in Table 5.

Table 5. Aldol reaction between benzaldehydes and acetone with $\mathbf{6} \mathbf{a}^{\text {a }}$.

\begin{tabular}{|c|c|c|}
\hline Benzaldehyde derivative & Yield (\%) & $\boldsymbol{e r}(\boldsymbol{\%})(\boldsymbol{R}: \mathbf{S})$ \\
\hline$p$-nitrobenzaldehyde & 50 & $84.5: 15.5$ \\
\hline$o$-nitrobenzaldehyde & 5 & n.d \\
\hline m-nitrobenzaldehyde & 19 & $82.5: 17.5$ \\
\hline$p$-bromobenzaldehyde & 22 & $94.5: 5.5$ \\
\hline$p$-methylbenzaldehyde & 7 & n.d. \\
\hline o-chlorobenzaldeyde & 39 & $80: 20$ \\
\hline
\end{tabular}

${ }^{a}$ Reaction conditions: $1 \mathrm{mmol}$ of benzaldehyde derivative, 2 $\mathrm{mL}$ of acetone, $20 \mathrm{~mol} \%$ of organocatalyst $\mathbf{6 a}, 5$ days, room temperature; n.d. (not determined).
Moderate to low conversions were obtained with all substrates and the best er were obtained when $p$ bromobenzaldehyde was used, 94.5:5.5 (R:S).

\section{EXPERIMENTAL SECTION}

Commercially available compounds were used without further purification. All solvents were dried prior to use following standard procedures. Melting points were determined using a FALC melting point apparatus (open capillary method). Optical rotations were measured with an Optical Activity AA-5 polarimeter. NMR spectra were recorded at room temperature on a Bruker Avance III 400 $\mathrm{MHz}$ (100 MHz for 13C). TMS was used as the internal standard and chemical shifts are given in ppm. Infrared spectra were recorded on an Agilent Technologies Cary 630 FTIR in the ATR mode. High-resolution mass spectra (HRMS) were obtained on a TOF VG Autospect M spectrometer with electrospray ionization (ESI).

\section{Organocatalyst synthesis}

Compounds $\mathbf{1}$ and $\mathbf{2}$ were synthesized according to previously described procedures. $[15,18,19]$

\section{General procedure for the synthesis of compounds 3,4} and 5

In a two-neck round bottom flask, equipped with a dropping funnel and a septum, $10 \mathrm{mmol}$ of $2(2.33 \mathrm{~g}), 10$ mmol of $\mathrm{NEt}_{3}(1.4 \mathrm{~mL})$ and $35 \mathrm{~mL}$ of THF were added. A solution of $10 \mathrm{mmol}$ of the amine in $10 \mathrm{~mL}$ of THF was added to the dropping funnel, the reaction mixture was cooled to $0{ }^{\circ} \mathrm{C}$ and placed in an inert atmosphere. With a syringe, $10 \mathrm{mmol}$ of ethyl chloroformate $(1.5 \mathrm{~mL})$ were slowly added and the reaction mixture was stirred during $1.5 \mathrm{~h}$ at room temperature. Subsequently, the amine was added dropwise, and the solution was stirred for $24 \mathrm{~h}$ at room temperature. The solvent was evaporated, and the residue was dissolved in dichloromethane and washed with water. The organic phase was dried over anhydrous $\mathrm{Na}_{2} \mathrm{SO}_{4}$ and filtered. After evaporating the solvent, the product was purified as described below.

\section{(R)-N-(2-hydroxyphenyl)-3-(tert-butoxycarbonyl)-1,3- thiazolidine-4-carboxamide 3}

The product was purified by silica gel column chromatography (AcOEt/hexane 1:2) to afford a white solid. Yield: $32 \%$. Mp: $68-71^{\circ} \mathrm{C}[\alpha]_{D}^{20}=-139.6\left(c 1.1, \mathrm{CH}_{2} \mathrm{Cl}_{2}\right)$. IR $\left(\mathrm{cm}^{-1}\right): 745,752,1103,1148,1157,1254,1285,1363,1375$, $1388,1456,1522,1529,1534,1540,1654,1663,1670$, 1675, 2973. ${ }^{1} \mathrm{H}$ NMR (DMSO-d6), $\delta$ (ppm): 1.39 (s, 9H, $\left.\mathrm{CH}_{3}\right) ; 3.18\left(\mathrm{dd}, 1 \mathrm{H}, \mathrm{CH}_{2}, \mathrm{~J}=4.8 \mathrm{~Hz}, \mathrm{~J}=12.0 \mathrm{~Hz}\right) ; 3.38-3.49$ $\left(\mathrm{m}, 1 \mathrm{H}, \mathrm{CH}_{2}\right) ; 4.42\left(\mathrm{~d}, 1 \mathrm{H}, \mathrm{CH}_{2}, \mathrm{~J}=9.0 \mathrm{~Hz}\right) ; 4.62(\mathrm{~d}, 1 \mathrm{H}$, $\left.\mathrm{CH}_{2}, \mathrm{~J}=9.0 \mathrm{~Hz}\right) ; 4.73-4.89(\mathrm{~m}, 1 \mathrm{H}, \mathrm{CH}) ; 6.76-6.80(\mathrm{~m}, 1 \mathrm{H}$, Ar); 6.86-6.88 (m, 1H, Ar); 6.92-6.96 (m, 1H, Ar); 7.91 (d, $1 \mathrm{H}, \mathrm{Ar}, \mathrm{J}=6.8 \mathrm{HZ}), 9.21(\mathrm{~s}, 1 \mathrm{H}, \mathrm{NH}), 9.89(\mathrm{sl}, 1 \mathrm{H}, \mathrm{OH}) .{ }^{13} \mathrm{C}$ NMR (DMSO-d6), $\delta$ (ppm): 28.4, 34.7, 49.8, 63.4, 81.0, $116.0,119.6,121.6,125.0,126.6,147.8,153.5,169.3$. HRMS (ESI): calculated for $\mathrm{C}_{15} \mathrm{H}_{21} \mathrm{~N}_{2} \mathrm{O}_{4} \mathrm{~S}[\mathrm{M}+\mathrm{H}]^{+} 325.1217$, found 325.1219 . 
(R)-N-(2-aminophenyl)-3-(tert-butoxycarbonyl)-1,3thiazolidine-4-carboxamide 4

The product was crystallized from diethyl ether to give a white solid that was used without further purification. Yield: 45\%. Mp: 71-72 ${ }^{\circ} \mathrm{C}$. [ []$_{D}^{20}=-45.2\left(c 1.0, \mathrm{CH}_{2} \mathrm{Cl}_{2}\right)$. IR $\left(\mathrm{cm}^{-1}\right)$ : $755, \quad 767, \quad 1045, \quad 1055, \quad 1206,1220, \quad 1253,1297,1309$, 1458,1519, 1681,1737, 2986, 3295. ${ }^{1} \mathrm{H}$ NMR $\left(\mathrm{CDCl}_{3}\right), \delta$ (ppm): 1.51 (s, 9H, $\left.\mathrm{CH}_{3}\right) ; 3.20-3.38\left(\mathrm{~m}, 1 \mathrm{H}, \mathrm{CH}_{2}\right) ; 3.45-3.62$ $\left(\mathrm{m}, 1 \mathrm{H}, \mathrm{CH}_{2}\right) ; 3.83\left(\mathrm{sl}, 2 \mathrm{H}, \mathrm{NH}_{2}\right) ; 4.38-4.57\left(\mathrm{~m}, 1 \mathrm{H}, \mathrm{CH}_{2}\right)$; $4.65\left(\mathrm{~d}, 1 \mathrm{H}, \mathrm{CH}_{2}, \mathrm{~J}=9.6 \mathrm{~Hz}\right) ; 4.74-4.89(\mathrm{~m}, 1 \mathrm{H}, \mathrm{CH}) ; 6.79(\mathrm{t}$, $2 \mathrm{H}, \mathrm{Ar}, \mathrm{J}=8.2 \mathrm{~Hz}$ ); $7.06(\mathrm{t}, 1 \mathrm{H}, \mathrm{Ar}, \mathrm{J}=7.2 \mathrm{~Hz}) ; 7.21-7.36(\mathrm{~m}$, $1 \mathrm{H}, \mathrm{Ar}) ; 8.04(\mathrm{sl}, 1 \mathrm{H}, \mathrm{NH}),{ }^{13} \mathrm{C}$ NMR $\left(\mathrm{CDCl}_{3}\right), \delta(\mathrm{ppm})$ : $28.3 ; 32.9 ; 49.9 ; 63.5 ; 82.4 ; 117.4 ; 119.2 ; 123.2 ; 125.5$; $127.4 ; 140.7,154.3 ; 168.9$.

\section{(R)- $N$-benzyl-3-(tert-butoxycarbonyl)-1,3-thiazolidine-4- carboxamide 5}

The product was purified by silica gel column chromatography (AcOEt/hexane 1:1) to afford a white solid. Yield: $68 \%$. Mp: $113-115^{\circ} \mathrm{C}$. $[\alpha]_{D}^{20}=-100.5\left(c 1.0, \mathrm{CH}_{2} \mathrm{Cl}_{2}\right)$. IR $\left(\mathrm{cm}^{-1}\right)$ : 694, 725, 1118, 1140, 1155, 1163, 1247, 1267, $1368,1376,1539,1653,1686,3303,3317 .{ }^{1} \mathrm{H}$ NMR $\left(\mathrm{CDCl}_{3}\right), \delta(\mathrm{ppm}): 1.42\left(\mathrm{~s}, 9 \mathrm{H}, \mathrm{CH}_{3}\right) ; 3.12-3.33(\mathrm{~m}, 1 \mathrm{H})$, $\mathrm{CH}_{2}$; 3.34-3.53 (m, 1H, CH $)$; 4.31-4.52 (m, 3H, $\left.\mathrm{CH}_{2}, \mathrm{CH}\right)$; $4.63\left(\mathrm{~d}, 1 \mathrm{H}, \mathrm{CH}_{2}, \mathrm{~J}=9.2 \mathrm{~Hz}\right) ; 4.67-4.81\left(\mathrm{~m}, 1 \mathrm{H}, \mathrm{CH}_{2}\right) ; 6.69$ (sl, $1 \mathrm{H}, \mathrm{NH}) ; 7.25-7.34$ (m, 5H, Ar). ${ }^{13} \mathrm{C}$ NMR (DMSO- $d 6$ ), $\delta(\mathrm{ppm}): 27.8,35.0,42.1,49.1,62.6,80.0,126.7,127.1$, 128.1, 139.3, 152.8, 170.1. HRMS (ESI): calculated for $\mathrm{C}_{16} \mathrm{H}_{23} \mathrm{~N}_{2} \mathrm{O}_{3} \mathrm{~S}[\mathrm{M}+\mathrm{H}]^{+}$323.1424, found 323.1427.

\section{General procedure for the synthesis of compounds 6 and} 7

In a two-neck round bottom flask, in an inert atmosphere and equipped with a septum, $10 \mathrm{mmol}(3.23 \mathrm{~g})$ of compound 4 and $60 \mathrm{~mL}$ of dry dichloromethane were added. With a syringe, $11 \mathrm{mmol}$ of phenyl isothiocyanate or 3,5bis(trifluoromethyl)phenyl isothiocyanate was added dropwise and the reaction was stirred for $48 \mathrm{~h}$, at room temperature. The solvent was evaporated and the product was purified as described below.

\section{(R)- $N$-[2-(3-phenylthioureido)phenyl]-3-(tert-}

\section{butoxycarbonyl)-1,3-thiazolidine-4-carboxamide 6}

The product was purified by silica gel column chromatography (AcOEt/hexane 1:1) to afford beige solid. Yield: $81 \%$. Mp: $115-117{ }^{\circ} \mathrm{C}$. $\left.[\alpha]\right]_{D}^{20}=-33.3\left(c 1.1, \mathrm{CH}_{2} \mathrm{Cl}_{2}\right)$. IR $\left(\mathrm{cm}^{-1}\right): 755,767,798,1015,1044,1055,1078,1221$, $1257,1458,1520,1680,1738,2963,3297 .{ }^{1} \mathrm{H}$ NMR $\left(\mathrm{CDCl}_{3}\right), \delta(\mathrm{ppm}): 1.48\left(\mathrm{~s}, 9 \mathrm{H}, \mathrm{CH}_{3}\right) ; 3.15-3.34(\mathrm{~m}, 2 \mathrm{H}$, $\left.\mathrm{CH}_{2}\right)$; 4.97-4.69 (m, 2H, $\left.\mathrm{CH}_{2}\right)$; 4.76-4.96 (m, 1H, CH); 7.19$7.23(\mathrm{~m}, 1 \mathrm{H}, \mathrm{Ar}) ; 7.30-7.35(\mathrm{~m}, 3 \mathrm{H}, \mathrm{Ar}) 7.38-7.46(\mathrm{~m}, 4 \mathrm{H}$, Ar); $7.63(\mathrm{~d}, 1 \mathrm{H}, \mathrm{Ar}, \mathrm{J}=8.0 \mathrm{~Hz}) 7.88(\mathrm{~s}, 1 \mathrm{H}, \mathrm{NH}) ; 8.01(\mathrm{sl}$, $1 \mathrm{H}, \quad \mathrm{NH}) ; 9.00 \quad(\mathrm{~s}, \quad 1 \mathrm{H}, \quad \mathrm{NH}) .{ }^{13} \mathrm{C} \quad \mathrm{NMR}\left(\mathrm{CDCl}_{3}\right), \delta$ (ppm):28.3, 33.5; 49.8, 63.7, 82.1, 125.2, 125.4, 126.5, 127.3, 127.8, 128.3, 129.8, 130.9, 133.0, 136.6, 154.0, 169.9, 180.0. HRMS (ESI): calculated for $\mathrm{C}_{22} \mathrm{H}_{27} \mathrm{~N}_{4} \mathrm{O}_{3} \mathrm{~S}_{2}[\mathrm{M}+\mathrm{H}]^{+}$ 459.1519, found 459.1518 .
(R)- $N$-[2-(3-(3,5-bis(trifluoromethyl)phenyl)thioureido) phenyl]-3-(tert-butoxycarbonyl)-1,3-thiazolidine-4carboxamide 7

The product, a white solid, was recrystallized from diethyl ether/hexane. Yield: $97 \%$. Mp: $97-99{ }^{\circ} \mathrm{C}$. $\left.[\alpha]\right]_{D}^{20}=7.5(c 2.0$, $\mathrm{CH}_{2} \mathrm{Cl}_{2}$ ). IR $\left(\mathrm{cm}^{-1}\right): 681,1107,1126,1170,1274,1368$, 1379, 1471, 1510, 1656, 1692, 1707, 2979, 3241. ${ }^{1} \mathrm{H}$ NMR $\left(\mathrm{CDCl}_{3}\right), \delta(\mathrm{ppm}): 1.44\left(\mathrm{~s}, 9 \mathrm{H}, \mathrm{CH}_{3}\right) ; 3.23-3.35(\mathrm{~m}, 2 \mathrm{H}$, $\left.\mathrm{CH}_{2}\right)$; 4.42-4.57 (m, $\left.2 \mathrm{H}, \mathrm{CH}_{2}\right)$; 4.77-4.92 (m, $\left.1 \mathrm{H}, \mathrm{CH}\right) ; 7.16-$ $7.24(\mathrm{~m}, 2 \mathrm{H}, \mathrm{Ar}) ; 7.29-7.39$ (m, 1H, Ar); 7.47-7.57 (m, $1 \mathrm{H}$, Ar); 7.65 (s, 1H, Ar); 8.09 (s, 2H, Ar); 8.30 (s, 1H, NH); $8.72(\mathrm{sl}, 1 \mathrm{H}, \mathrm{NH}) ; 9.95(\mathrm{~s}, 1 \mathrm{H}, \mathrm{NH}) .{ }^{13} \mathrm{C} \mathrm{NMR}\left(\mathrm{CDCl}_{3}\right), \delta$ (ppm): 28.2; 33.5; 49.82; 63.44; 82.48; 118.7 (t, 1C, J=10.8 $\mathrm{Hz}$ ); 123.0 (q, 2C, J=271.0 Hz); 123.5; 125.9; 127.6; 128.0; $128.5 ; 130.9 ; 132.0$ (q, 2C, J=34.0 Hz); 132.4; 140.0; 154.1; 170.9; 180.5. HRMS (ESI): calculated for $\mathrm{C}_{24} \mathrm{H}_{25} \mathrm{~F}_{6} \mathrm{~N}_{4} \mathrm{O}_{3} \mathrm{~S}_{2}$ $[\mathrm{M}+\mathrm{H}]^{+}$595.1267, found 595.1265.

(R)- $N$-(2-benzamidophenyl)-3-(tert-butoxycarbonyl)-1,3thiazolidine-4-carboxamide 8

In a two-neck round bottom flask, in an inert atmosphere and equipped with a septum, $10 \mathrm{mmol}$ (3.23 g) of compound $\mathbf{4}$, $12 \mathrm{mmol}$ of $\mathrm{NEt}_{3}(1.7 \mathrm{~mL})$ and $60 \mathrm{~mL}$ of dry dichloromethane were added. With a syringe, $12 \mathrm{mmol}$ of benzoyl chloride $(1.4 \mathrm{~mL})$ was added dropwise and the reaction was stirred overnight, at room temperature. The solvent was evaporated and the product purified by silica gel column chromatography (AcOEt/hexane 1:1) to afford a white solid. Yield: $84 \% .160-161{ }^{\circ} \mathrm{C} .[\alpha]_{D}^{20}=-73.2(c 1.0$, $\left.\mathrm{CH}_{2} \mathrm{Cl}_{2}\right)$. IR $\left(\mathrm{cm}^{-1}\right): 720,752,1112,1159,1309,1367,1474$, 1513, $1658,1702,3312 .{ }^{1} \mathrm{H}$ NMR $\left(\mathrm{CDCl}_{3}\right), \delta(\mathrm{ppm}): 1.42(\mathrm{~s}$, $\left.9 \mathrm{H}, \mathrm{CH}_{3}\right)$; 3.15-3.60 (m, 2H, $\left.\mathrm{CH}_{2}\right)$; 4.18-4.46 (m, $\left.1 \mathrm{H}, \mathrm{CH}_{2}\right)$; $4.56\left(\mathrm{~d}, 1 \mathrm{H}, \mathrm{CH}_{2}, \mathrm{~J}=8.8 \mathrm{~Hz}\right) ; 4.65-5.03(\mathrm{~m}, 1 \mathrm{H}, \mathrm{CH}) ; 7.18$ 7.26 (m, 2H, Ar); 7.40-7.73 (m, 5H, Ar); 7.95-7.97 (m, 2H, $\mathrm{Ar}) ; 8.81(\mathrm{~s}, 1 \mathrm{H}, \mathrm{NH}) ; 8.97(\mathrm{sl}, 1 \mathrm{H}, \mathrm{NH}) .{ }^{13} \mathrm{C}$ NMR (DMSO$d 6), \delta(\mathrm{ppm}): 28.4,34, .6,49.6,63.6,80.9,125.2,125.8$, 126.1, 128.1, 128.9, 131.1, 131.6, 132.2, 134.6, 153.4, 166.1, 169.8. HRMS (ESI): calculated for $\mathrm{C}_{22} \mathrm{H}_{26} \mathrm{~N}_{3} \mathrm{O}_{4} \mathrm{~S}[\mathrm{M}+\mathrm{H}]^{+}$ 428.1639 , found 428.1637 .

\section{General procedure for the synthesis of compounds 3a-8a}

To $3 \mathrm{mmol}$ of the $N$-Boc protected thiazolidine, at $0{ }^{\circ} \mathrm{C}$, $12 \mathrm{~mL}$ of $95 \%$ formic acid was added dropwise. The reaction mixture was slowly warmed up to room temperature and stirred overnight. The reaction mixture was cooled again to 0 ${ }^{\circ} \mathrm{C}$, diluted with water and treated with solid $\mathrm{NaHCO}_{3}$, to $\mathrm{pH}=7$. The aqueous phase was extracted with dichloromethane, dried over anhydrous $\mathrm{Na}_{2} \mathrm{SO}_{4}$ and filtered. The solvent was evaporated and the product was purified as described below.

\section{(R)-N-(2-hydroxyphenyl)-1,3-thiazolidine-4-carboxamide 3a}

The product was purified by recrystallization from dichloromethane/hexane to give a white solid. Yield: $85 \%$. Mp: $164{ }^{\circ} \mathrm{C}$. $[\alpha]_{D}^{20}=-15.1\left(c 1.0, \mathrm{CH}_{2} \mathrm{Cl}_{2}\right)$. IR $\left(\mathrm{cm}^{-1}\right): 762$, 1107, 1284, 1375, 1456, 1537, 1587, 1647, 3093, 3276, 3334. ${ }^{1} \mathrm{H} \mathrm{NMR}\left(\mathrm{CDCl}_{3}\right), \delta(\mathrm{ppm}): \delta 3.20\left(\mathrm{dd}, 1 \mathrm{H}, \mathrm{CH}_{2}, \mathrm{~J}=8.0\right.$ $\mathrm{Hz}, \mathrm{J}=11.4 \mathrm{~Hz}) ; 3.48\left(\mathrm{dd}, 1 \mathrm{H}, \mathrm{CH}_{2}, \mathrm{~J}=4.0 \mathrm{~Hz}, \mathrm{~J}=11.4 \mathrm{~Hz}\right)$; $3.94\left(\mathrm{~d}, 1 \mathrm{H}, \mathrm{CH}_{2}, \mathrm{~J}=10.2 \mathrm{~Hz}\right) ; 4.28\left(\mathrm{~d}, 1 \mathrm{H}, \mathrm{CH}_{2}, \mathrm{~J}=10.2 \mathrm{~Hz}\right)$; 
$4.35(\mathrm{dd}, 1 \mathrm{H}, \mathrm{CH}, \mathrm{J}=4.0 \mathrm{~Hz}, \mathrm{~J}=8.0 \mathrm{~Hz}) ; 6.77-6.82(\mathrm{~m}, 1 \mathrm{H}$, Ar); 6.92-6.96 (m, 2H, Ar); 7.04-7.08 (m, 1H, Ar); 8.94 (s, $1 \mathrm{H}, \mathrm{NH}) ; 9.32(\mathrm{~s}, 1 \mathrm{H}, \mathrm{OH}) .{ }^{13} \mathrm{C} \mathrm{NMR}\left(\mathrm{CDCl}_{3}\right), \delta(\mathrm{ppm})$ : $35.1 ; 53.3 ; 65.6 ; 120.0 ; 120.3 ; 122.1 ; 124.8 ; 127.4 ; 148.9$; 171.1. HRMS (ESI): calculated for $\mathrm{C}_{10} \mathrm{H}_{13} \mathrm{~N}_{2} \mathrm{O}_{2} \mathrm{~S}[\mathrm{M}+\mathrm{H}]^{+}$ 225.0692, found 225.0694.

\section{(R)-N-(2-aminophenyl)-1,3-thiazolidine-4-carboxamide $4 \mathbf{a}$}

The product was obtained pure as an orange oil. Yield: $81 \%$. $[\alpha]_{D}^{20}=-49.1\left(c 1.1, \mathrm{CH}_{2} \mathrm{Cl}_{2}\right) . \mathrm{IR}\left(\mathrm{cm}^{-1}\right): 669,1095,1261$, 1508, 1651, 3447. ${ }^{1} \mathrm{H}$ NMR $\left(\mathrm{CDCl}_{3}\right), \delta(\mathrm{ppm}): 3.17(\mathrm{dd}, 1 \mathrm{H}$, $\left.\mathrm{CH}_{2}, \mathrm{~J}=7.6 \mathrm{~Hz} ; \mathrm{J}=11.2 \mathrm{~Hz}\right) ; 3.52\left(\mathrm{dd}, 1 \mathrm{H}, \mathrm{CH}_{2}, \mathrm{~J}=4.0 \mathrm{~Hz} ; \mathrm{J}=\right.$ $11.2 \mathrm{~Hz}) ; 4.07$ (d, 1H, $\left.\mathrm{CH}_{2}, \mathrm{~J}=10.0 \mathrm{~Hz}\right) ; 4.30$ (d, 1H, $\mathrm{CH}_{2}$, $\mathrm{J}=10.0 \mathrm{~Hz}) ; 4.33$ (dd, 1H, CH J=4.0 Hz; J= 7.6 Hz); 6.776.81 (m, 2H, Ar); 7.03-7.07 (m, 1H, Ar); 7.20-7.22 (m, 1H, $\mathrm{Ar}) ; 8.94(\mathrm{~s}, 1 \mathrm{H}, \mathrm{NH}) .{ }^{13} \mathrm{C} \mathrm{NMR}\left(\mathrm{CDCl}_{3}\right), \delta(\mathrm{ppm}): 35.4$, 53.5, 66.2, 117.9, 119.4, 123.6, 125.0, 127.2, 140.7, 169.8. HRMS (ESI): calculated for $\mathrm{C}_{10} \mathrm{H}_{14} \mathrm{~N}_{3} \mathrm{OS}[\mathrm{M}+\mathrm{H}]^{+} 224.0852$, found 224.0844 .

\section{(R)- $N$-benzyl-1,3-thiazolidine-4-carboxamide 5a}

The product was purified by recrystallization from dichloromethane/hexane. Yield: $81 \%$. Mp: $40-42{ }^{\circ} \mathrm{C} .[\alpha]_{D}^{20}=$ -30.5 (c1.0, $\left.\mathrm{CH}_{2} \mathrm{Cl}_{2}\right)$. IR ( $\left.\mathrm{cm}^{-1}\right)$ : 686, 710, 826, 1545, 1642, 3285. ${ }^{1} \mathrm{H}$ NMR $\left(\mathrm{CDCl}_{3}\right), \delta(\mathrm{ppm}): 2.39(\mathrm{sl}, 1 \mathrm{H}, \mathrm{NH}) ; 3.16$ $\left(\mathrm{dd}, 1 \mathrm{H}, \mathrm{CH}_{2}, \mathrm{~J}=7.6 \mathrm{~Hz}, \mathrm{~J}=10.8 \mathrm{~Hz}\right) ; 3.51\left(\mathrm{dd}, 1 \mathrm{H}, \mathrm{CH}_{2}\right.$, $\mathrm{J}=4.0 \mathrm{~Hz}, \mathrm{~J}=10.8 \mathrm{~Hz}) ; 3.94\left(\mathrm{~d}, 1 \mathrm{H}, \mathrm{CH}_{2}, \mathrm{~J}=9.8 \mathrm{~Hz}\right) ; 4.19$ (dd, $\left.1 \mathrm{H}, \mathrm{CH}_{2}, \mathrm{~J}=4.0 \mathrm{~Hz}, \mathrm{~J}=7.6 \mathrm{~Hz}\right) 4.23(\mathrm{~d}, 1 \mathrm{H}, \mathrm{CH}, \mathrm{J}=9.8$ $\mathrm{Hz})$; 4.39-4.50 (m, 2H, $\left.\mathrm{CH}_{2}\right)$; 7.25- $7.36(\mathrm{~m}, 5 \mathrm{H}$,

Ar). ${ }^{13} \mathrm{C} \mathrm{NMR}\left(\mathrm{CDCl}_{3}\right), \delta$ (ppm): 35.4; 43.4; 53.6; 66.0; $127.6 ; 127.7 ; 128.8 ; 138.1 ; 170.7$. HRMS (ESI): calculated for $\mathrm{C}_{11} \mathrm{H}_{15} \mathrm{~N}_{2} \mathrm{OS}[\mathrm{M}+\mathrm{H}]^{+}$223.0900, found 223.0899.

\section{(R)-N-[2-(3-phenylthioureido)phenyl]-1,3-thiazolidine-4- carboxamide 6 a}

The pure product, a yellow solid, was obtained by washing several times with diethyl ether. Yield: $81 \%$. Mp: 78-80 ${ }^{\circ} \mathrm{C}$. $\left.[\alpha]\right]_{D}^{20}=+25.0\left(c 1.0, \mathrm{CH}_{2} \mathrm{Cl}_{2}\right)$. IR $\left(\mathrm{cm}^{-1}\right): 692,758,1261$, 1313, 1448, 1522, 1670, 3267. ${ }^{1} \mathrm{H} \mathrm{NMR}\left(\mathrm{CDCl}_{3}\right), \delta(\mathrm{ppm})$ : 2.56 (sl, 1H, NH); 3.09 (dd, 1H, $\mathrm{CH}_{2}, \mathrm{~J}=7.6 \mathrm{~Hz} ; \mathrm{J}=11.2 \mathrm{~Hz}$ ); $3.42\left(\mathrm{dd}, 1 \mathrm{H}, \mathrm{CH}_{2}, \mathrm{~J}=4.0 \mathrm{~Hz}, \mathrm{~J}=11.2 \mathrm{~Hz}\right) ; 3.89\left(\mathrm{~d}, 1 \mathrm{H}, \mathrm{CH}_{2}\right.$, $\mathrm{J}=10.0 \mathrm{~Hz}) ; 4.15\left(\mathrm{~d}, 1 \mathrm{H}, \mathrm{CH}_{2}, \mathrm{~J}=10.0 \mathrm{~Hz}\right) ; 4.26(\mathrm{dd}, 1 \mathrm{H}$, $\mathrm{CH} \mathrm{J}=4.0 \mathrm{~Hz}, \mathrm{~J}=7.6 \mathrm{~Hz}) ; 7.09-7.13(\mathrm{~m}, 1 \mathrm{H}, \mathrm{Ar}) ; 7.17-7.24$ (m, 2H, Ar); 7.40-7.50 (m, 3H, Ar); 7.66 (d, 1H, Ar, J=8.0 $\mathrm{Hz})$; 7.86-7.88 (m, 2H, Ar); 9.04 (s, 1H, NH); 9.34 (s, 1H, $\mathrm{NH}) .{ }^{13} \mathrm{C}$ NMR $\left(\mathrm{CDCl}_{3}\right), \delta(\mathrm{ppm}): 34.4 ; 53.0 ; 64.4 ; 122.0$; $122.3 ; 124.1 ; 124.4 ; 124.9 ; 127.0 ; 128.6 ; 130.5 ; 132.2$; 134.2; 169.4; 180.9. HRMS (ESI): calculated for $\mathrm{C}_{17} \mathrm{H}_{19} \mathrm{~N}_{4} \mathrm{OS}_{2}[\mathrm{M}+\mathrm{H}]^{+}$359.0995, found 359.0997.

\section{(R)- $N$-[2-(3-(3,5-bis(trifluoromethyl)phenyl)thioureido) phenyl]-1,3-thiazolidine-4-carboxamide 7a}

The product was purified by recrystallization from diethyl ether/hexane to give a white solid. Yield: $86 \%$ mp: 124-125 $\left.{ }^{\circ} \mathrm{C} .[\alpha]\right]_{D}^{20}=+25.0\left(c 1.0, \mathrm{CH}_{2} \mathrm{Cl}_{2}\right)$. IR $\left(\mathrm{cm}^{-1}\right): 681,1130$, $1174,1277,1383,1525,1657,3288 .{ }^{1} \mathrm{H}$ NMR $\left(\mathrm{CDCl}_{3}\right), \delta$ (ppm): 3.07 (dd, 1H, $\mathrm{CH}_{2}, \mathrm{~J}=7.4 \mathrm{~Hz}, \mathrm{~J}=11.0 \mathrm{~Hz}$ ); 3.40 (dd, $\left.1 \mathrm{H}, \mathrm{CH}_{2}, \mathrm{~J}=3.2 \mathrm{~Hz}, \mathrm{~J}=11.0 \mathrm{~Hz}\right) ; 4.02\left(\mathrm{~d}, 1 \mathrm{H}, \mathrm{CH}_{2}, \mathrm{~J}=10.0\right.$ $\mathrm{Hz}) ; 4.24\left(\mathrm{~d}, 1 \mathrm{H}, \mathrm{CH}_{2}, \mathrm{~J}=10.0 \mathrm{~Hz}\right) ; 4.36(\mathrm{dd}, 1 \mathrm{H}, \mathrm{CH}, \mathrm{J}=3.2$ $\mathrm{Hz}, \mathrm{J}=7.4 \mathrm{~Hz})$; 7.17-7.26 (m, 2H, Ar); 7.34-7.37 (m, 1H, $\mathrm{Ar})$; 7.56-7.57 (m, 1H, Ar); 7.67 (s, 1H, Ar); 8.02 (s, 2H, $\mathrm{Ar}) ; 8.46$ (sl, 2H, NH); 9.49 (s, 1H, NH). ${ }^{13} \mathrm{C} \mathrm{NMR}\left(\mathrm{CDCl}_{3}\right)$, $\delta$ (ppm): 34.9; 53.2; 66.1; $119.1(\mathrm{t}, 1 \mathrm{C}, \mathrm{J}=3,5 \mathrm{~Hz}) ; 123.0(\mathrm{q}$, 2C, J=271.0 Hz); 124.1; 124.2; 125.5; 127.5; 128.5; 129.0; 132.1 (q, 2C, J=34.0 Hz); 132.8; 139.7; 171.4; 180.7. HRMS (ESI): calculated for $\mathrm{C}_{19} \mathrm{H}_{17} \mathrm{~F}_{6} \mathrm{~N}_{4} \mathrm{OS}_{2}[\mathrm{M}+\mathrm{H}]^{+}$495.0742, found 495.0743 .

\section{(R)-N-(2-benzamidophenyl)-1,3-thiazolidine-4- carboxamide 8a}

The pure product, a white solid, was obtained by washing several times with diethyl ether. Yield: $80 \%$. Mp: 158-160 ${ }^{\circ} \mathrm{C}$. $[\alpha]_{D}^{20}=-10.0\left(\mathrm{c} 1.0, \mathrm{CH}_{2} \mathrm{Cl}_{2}\right)$. IR $\left(\mathrm{cm}^{-1}\right): 686,747,1256$, 1320, 1507, 1644, 3283. ${ }^{1} \mathrm{H}$ NMR $\left(\mathrm{CDCl}_{3}\right), \delta(\mathrm{ppm}): 2.61$ $(\mathrm{sl}, 1 \mathrm{H}, \mathrm{NH}) ; 3.19$ (dd, 1H, $\left.\mathrm{CH}_{2}, \mathrm{~J}=7.8 \mathrm{~Hz}, \mathrm{~J}=11.0 \mathrm{~Hz}\right) ; 3.54$ $\left(\mathrm{dd}, 1 \mathrm{H}, \mathrm{CH}_{2}, \mathrm{~J}=3.8 \mathrm{~Hz}, \mathrm{~J}=11.0 \mathrm{~Hz}\right) ; 3.98\left(\mathrm{~d}, 1 \mathrm{H}, \mathrm{CH}_{2}, \mathrm{~J}=\right.$ $9.8 \mathrm{~Hz}) ; 4.26\left(\mathrm{~d}, 1 \mathrm{H}, \mathrm{CH}_{2}, \mathrm{~J}=9.8 \mathrm{~Hz}\right) ; 4.38-4.40(\mathrm{~m}, 1 \mathrm{H}$, $\mathrm{CH})$; 7.20-7.24 (m, 1H, Ar); 7.29-7.32 (m, 2H, Ar); 7.48$7.58(\mathrm{~m}, 3 \mathrm{H}, \mathrm{Ar}) ; 7.80-7.82(\mathrm{~m}, 1 \mathrm{H}, \mathrm{Ar}) ; 7.94-7.96(\mathrm{~m}, 2 \mathrm{H}$, $\mathrm{Ar}) ; 9.07$ (s, 1H, NH); 9.39 (s, 1H, NH). ${ }^{13} \mathrm{C} \mathrm{NMR}\left(\mathrm{CDCl}_{3}\right)$, $\delta$ (ppm): 34.3; 52.3; 65.1; 123.6; 125.1; 125.2; 125.8; 126.4; $127.7 ; 128.7 ; 130.1 ; 131.0 ; 133.0 ; 164.8 ; 169.7$. HRMS (ESI): calculated for calculated for $\mathrm{C}_{17} \mathrm{H}_{18} \mathrm{~N}_{3} \mathrm{O}_{2} \mathrm{~S}[\mathrm{M}+\mathrm{H}]^{+}$ 328.1114 , found 328.1115 .

\section{General procedure for aldol reactions}

In a $10 \mathrm{ml}$ round bottom flask $20 \mathrm{~mol} \%$ of catalyst, $2 \mathrm{ml}$ of solvent, $4 \mathrm{mmol}$ of acetone and $10 \mathrm{~mol} \%$ of additive (if any) were added. The reaction mixture was stirred for 15 minutes and then $1 \mathrm{mmol}$ of aldehyde was added. The reaction was stirred 5 days at room temperature. The solvent was evaporated, and the product was purified by silica gel column chromatography using AcOEt/Hex mixtures (usually $1: 2,1: 3$ or $1: 4$, depending on the catalyst and the aldehyde). Conversions were determined by ${ }^{1} \mathrm{H} \quad \mathrm{NMR}$ and the enantiomeric excesses by polarimetry, by comparison with literature data[20,21].

\section{CONCLUSION}

Novel chiral organocatalysts with a thiazolidine moiety were synthesized in good yields. These compounds, with different amide and thioureia functionalities at $\mathrm{C} 4$, were tested in the asymmetric aldol reaction of acetone with $p$ nitrobenzaldehyde. Products with moderate yields and er up to $84.5: 15.5(R: S)$ were obtained. The reaction was carried out in the presence of additives in order to determine their effect on yield and selectivity. With some of the organocatalysts an improvement was observed. With the most selective organocatalyst the scope of the reaction was evaluated. The best result, er of 94.5:5.5 (R:S), was obtained when p-bromobenzaldehyde was used.

\section{CONFLICT OF INTEREST}

The authors declare no conflict of interest, financial or otherwise. 


\section{ACKNOWLEDGEMENTS}

Thanks are due to Coimbra Chemistry Centre (CQC), supported by the Portuguese Agency for Scientific Research, Fundação para a Ciência e a Tecnologia (FCT) through Project UID/QUI/00313/2019. We also acknowledge the UC-NMR facility for obtaining the NMR data (www.nmrccc.uc.pt).

\section{REFERENCES}

[1] Pellissier, H. Tetrahedron, 2007, 63, 9267-9331.

[2] Seayad, J.; List, B. Org. Biomol. Chem., 2005, 3, 719-724.

[3] Ricci, A. ISRN Org. Chem., 2014, 1-29.

[4] Gaunt, M.J.; Johansson, C.C.C.; McNally, A.; Vo, N.T. Drug Discov. Today, 2007, 12, 8-27.

[5] Pellissier, H. Adv. Synth. Catal., 2012, 354, 237-294.

[6] Hajos, Z.G.; Parrish, D.R. J. Org. Chem., 1974, 39, 1615-1621.

[7] Guillena, G.; Nájera, C.; Ramón, D.J. Tetrahedron Asymmetry, 2007, 18, 2249-2293.

[8] Geary, L.M.; Hultin, P.G. Tetrahedron Asymmetry, 2009, 20, 131-173.

[9] Yu, N.; Han, S.; Yu, H. Tetrahedron, 2015, 71, 4665-4669.

[10] Gao, Q.; Liu, Y.; Lu, S.; Li, C.Chinese J. Catal., 2011, 32, 899903.

[11] Zhao, W.; Qu, C.; Yang, L.; Cui, Y. Chinese J. Catal., 2015, 36, 367-371.

[12] List, B.; Lerner, R.A.; Barbas III, C.F. J. Am. Chem. Soc., 2000, 122, 2395-2396.

[13] Liu, J.; Wang, L. Synthesis (Stuttg)., 2017, 49, 960-972.

[14] Sakthivel, K.; Notz, W.; Bui, T.; Barbas III, C.F. J. Am. Chem. Soc., 2001, 123, 5260-5267.

[15] Rambo, R.S.; Schneider, P.H. Tetrahedron Asymmetry, 2010, 21, 2254-2257.

[16] Rambo, R.S.; Gross Jacoby, C.; Da Silva, T.L.; Schneider, P.H.; Jacoby, C.G.; Da Silva, T.L.; Schneider, P.H. Tetrahedron Asymmetry, 2015, 26, 632-637.

[17] Serra, M.E.S.; Costa, D.; Murtinho, D.; Tavares, N.C.T.; Pinho e Melo, T.M.V.D. Tetrahedron, 2016, 72, 5923-5927.

[18] Sutcliffe, O.B.; Storr, R.C.; Gilchrist, T.L.; Rafferty, P. J. Chem. Soc. Perkin 1, 2001, 15, 1795-1806.

[19] Seki, M.; Mori, Y.; Hatsuda, M.; Yamada, S. J. Org. Chem., 2002, 67, 5527-5536

[20] Tang, Z.; Jiang, F.; Cui, X.; Gong, L.-Z.; Mi, A.-Q.; Jiang, Y.-Z.; Wu, Y.-D. Proc. Natl. Acad. Sci. U. S. A., 2004, 101, 5755-5760.

[21] Wagner, M.; Contie, Y.; Ferroud, C.; Revial, G. Int. J. Org. Chem., 2014, 04, 55-67.
[22]

[23]
Zhang, Z.; Bao, Z.; Xing, H. Org. Biomol. Chem., 2014, 12, 3151-3162.

Tsakos, M.; Kokotos, C.G. Tetrahedron, 2013, 69, 10199-10222. He, C.; Ren, X.; Feng, Y.; Chai, Y.; Zhang, S.; Chen, W Tetrahedron Lett., 2015, 56, 4036-4038.

Pratap Reddy Gajulapalli, V.; Lokesh, K.; Vishwanath, M.; Kesavan, V. RSC Adv., 2016, 6, 12180-12184.

Pratap Reddy Gajulapalli, V.; Vinayagam, P.; Kesavan, V. Org. Biomol. Chem., 2014, 12, 4186-4191.

Li, J.; Yang, G.; Qin, Y.; Yang, X.; Cui, Y. Tetrahedron Asymmetry, 2011, 22, 613-618.

Gajulapalli, V.P.R.; Vinayagam, P.; Kesavan, V. RSC Adv., 2015 5, 7370-7379.

Serra-Pont, A.; Alfonso, I.; Solà, J.; Jimeno, C. Org. Biomol. Chem., 2017, 15, 6584-6591.

Li, Y.; Yang, Q.; Xu, X.-Y.; Zhou, Y. Bai, J.; Wang, F.; Wang, L. A Can. J. Chem., 2011, 89, 1312-1318.

a Silva, T.L.; Miolo, L.M.F.; Sousa, F.S.S.; Brod, L.M.P Savegnago, L.; Schneider, P.H. Tetrahedron Lett., 2015, 56, 6674-6680.

Rojas Cabrera, H.; Huelgas, G.; Hernández Pérez, J.M.; Walsh, P.J.; Somanathan, R.; Anaya De Parrodi, C. Tetrahedron Asymmetry, 2015, 26, 163-172.

Xu, B.; Li, L.; Gou, S. Tetrahedron Asymmetry, 2013, 24, 15561561.

Wang, L.M.; Zhao, M.J.; Chen, Z.; Mu, H.W.; Jin, Y. Chirality, 2018, 30, 1005-1011.

Hong, L.; Sun, W.; Yang, D.; Li, G.; Wang, R. Chem. Rev., 2016, $116,4006-4123$.

Huang, X.-R.; Liu, Q.; Wang, J.; Xiao, J.-A.; Yang, H. Tetrahedron: Asymmetry, 2014, 25, 1590-1598.

Nakashima, K.; Hirashima, S.; Akutsu, H.; Koseki, Y.; Tada, N.; Itoh, A.; Miura, T. Tetrahedron Lett., 2015, 56, 558-561.

Eymur, S.; Akceylan, E.; Sahin, O.; Uyanik, A.; Yilmaz, M. Tetrahedron, 2014, 70, 4471-4477.

Naresh, T.; Kumar, T.P.; Haribabu, K.; Chandrasekhar, S. Tetrahedron Asymmetry, 2014, 25, 1340-1345

Kumar, T.P.; Vavle, N.C.; Patro, V.; Haribabu, K. Tetrahedron Asymmetry, 2014, 25, 457-461.

Bisticha, A.; Triandafillidi, I.; Kokotos, C.G. Tetrahedron Asymmetry, 2015, 26, 102-108.

Vlasserou, I.; Sfetsa, M.; Gerokonstantis, D.T.; Kokotos, C.G.; Moutevelis-Minakakis, P. Tetrahedron, 2018, 74, 2338-2349.

Bhowmick, S.; Mondal, A.; Ghosh, A.; Bhowmick, K.C. Tetrahedron: Asymmetry, 2015, 26, 1215-1244.

Gryko, D.; Zimnicka, M.; Lipiński, R. J. Org. Chem., 2007, 72, 964-970. 